articles containing details of simple experiments which the layman could carry out at home. To-day, increasing awareness of the social impact of science has changed the nature of popular science journals and now they usually seek to explain not only the mechanics of important scientific discoveries but also their significance for man and society. This is well brought out in a now journal called Spotlight on Science, which has been written by Dr. J. Gordon Cook for "the man in the street and his family". The first issue of this journal consists of notes and articles on such topics as bee behaviour, prospecting in Antarctica, high-frequency radio, fluorine, computing machines, mono-sodium glutamate, meteorology, the extraction of elements from sea-water, and the effects of environmental conditions on human beings. Each article is well written and shows that the author has taken considerable pains over the details of his information and the means of making it clear. Nine useful photographs add to the attractiveness of the journal; but these would have been more effective if spread throughout the whole journal rather than concentrated in the first half. Details of the journal may be obtained from the Merrow Publishing Co., Ltd., 23 Ganghill, Guildford, Surrey.

\section{Bollettino dell'Istituto di Alimentazione e Dietologia}

THE first number of the bulletin of the Institute of Nutrition and Dietetics, Rome, was issued in August 1950 and includes a description of the work that the Institute proposes to undertake (Bollettino dell'Istituto di Alimentazione e Dietologia, 1, No. 1, August 1950 ; pp. 56. 1, No. 2, October 1950; pp. 64. Rome: Editore 'Il Pensiero Scientifico). It appears that the founders of the Institute were fully alive to the ramifications of the subject of nutrition, for the work envisaged ranges from experimental food production to fundamental laboratory studies in physiology and biochemistry, and includes food technology, catering and dietetics in health and disease. The Institute is also to offer courses in nutrition at various levels, intended for medical officers, nurses, teachers, administrators, economists, agriculturalists, catering officers and cooks, and also non-technical courses for the man-in-the-street and the housewife. All these plans are in concordance with the resolutions adopted by the United Nations Food and Agriculture Conference at Hot Springs in 1943 and repeatedly re-emphasized by the Food and Agriculture Organization ever since. If these plans can be adequately carried through, Italy should be able to evolve and maintain a scientific food policy from which her people would derive great benefit. But to what extent this Institute will be able to influence government policy remains to be seen. The first two issues of the bulletin present reports of work already in progress (for example, on protein levels and albumin/globulin ratios in cases of gastric or duodenal ulcers or carcinoma of the digestive tract) and also diet sheots and recipes for therapeutic use. The second issue also includes very full extracts of the publication by the Food and Agriculture Organization on calorie requirements.

\section{Blight-resistance in Potato}

Dr. William Black, working at the Scottish Plant Breeding Station, Edinburgh, has produced several potato varieties resistant to attack by blight, Phytophthora infestans. He describes, in a recent paper (Proc. Roy. Soc. Edinburgh, B, 64, Part 2,
No. $10 ; 1950$ ), the occurrence of three strains, A $B$ and $C$, of the fungus. Strains $B$ and $C$ are more virulent than the common strain $A$, from which they probably arose by mutation. Specialized strains of blight may, under test conditions, alter in virulence ; but each can be maintained in continuous culture on a host plant to which it is specially adapted, without appreciable change. This mutability of pathogenic fungi is an incubus to the plant breeder; but Dr. Black now reports breeding experiments for resistance to all three strains. The existence of three genes is postulated: $R b$, conferring resistance to strains $\mathbf{A}$ and $\mathrm{B} ; R c$, resisting $\mathrm{A}$ and $\mathrm{C}$; and $R b c$, giving resistance to all three. Each gene is independent of the other in producing its effect, and is inherited independently in simple Mendelian fashion, though there is an excess of recessive individuals. The wild species Solanum demissum provides the source of resistant genes.

\section{University Education and Subsequent Careers}

AN excellent pamphlet, "Introduction to a University" (pp. 47; 1951), has been issued by the University of Birmingham and is designed to assist some of those who now have the chance of a university education but have had little opportunity of finding out what are the essentials of such an education. The greater part deals with the various careers open to university graduates in science and the humanities; but the pamphlet starts with a brief account of the main ideas about universities in general at the present time, especially as they relate to the undergraduate. This is followed by some account of the University of Birmingham itself and of undergraduate life at that University. There is a section on qualifications for admission to the University of Birmingham, and some information on salary scales in various careers is appended.

\section{Conference of British Universities}

A REPORT of proceedings at the Conference of the Home Universities, held at the University of London during December 15-16, 1950, has now been published (pp. 119 ; London: Association of Universities of the British Commonwealth, 1951 ; 1s.). It includes the text of addresses by Profs. W. Fisher Cassie, T. S. Simey, Sir Lionel Whitby and R. D. Waller at the session on "The University as a Regional Focus", by C. E. Escritt and T. R. Henn at the session on "National Service and the Universities", and by Dr. G. V. Allen and Sir Ronald Adam at that on "Overseas Students in British Universities", as well as summaries of the discussions.

\section{University of London: Appointments}

Dr. BernhaRD KATz, reader in experimental physiology in University College, has been appointed to the University chair of biophysics tenable in University College from January 1, 1952. The following titles have been conferred in respect of posts held at the places mentioned: professor of applied mechanics in the University on Dr. Hugh Ford (Imperial College of Science and Technology); professor of technical optics in the University on Dr. W. D. Wright (Imperial College of Science and Technology); professor of veterinary physiology in the University on Dr. E. C. Amoroso (Royal Veterinary College); professor of veterirary pathology in the University on Mr. T. J. Bosworth (Royal Veterinary College). 